\title{
BETHANECOL CHLORIDE FOR TREATMENT OF CLOMIPRAMINE-INDUCED ORGASMIC DYSFUNCTION IN MALES
}

\author{
Márcio Bernik, Antonio Hélio Guerra Vieira and Paula Villela Nunes
}

BERNIK M et al. Bethanecol chloride for treatment of clomipramine-induced orgasmic dysfunction in males. Rev. Hosp.

Clin. Fac. Med. S. Paulo 59(6):357-360, 2004.

PURPOSE: To investigate whether bethanecol chloride may be an alternative for the clinical management of clomipramine-induced orgasmic dysfunction, reported to occur in up to $96 \%$ of male users.

METHODS: In this study, 12 fully remitted panic disorder patients, complaining of severe clomipramine-induced ejaculatory delay, were randomly assigned to either bethanecol chloride tablets $(20 \mathrm{mg}$, as needed) or placebo in a randomized, double-blind, placebo-controlled, two-period crossover study. A visual analog scale was used to assess severity of the orgasmic dysfunction.

RESULTS: A clear improvement was observed in the active treatment period. No placebo or carry-over effects were observed.

CONCLUSION: These findings suggest that bethanecol chloride given 45 minutes before sexual intercourse may be useful for clomipramine-induced orgasmic dysfunction in males.

KEYWORDS: Orgasmic dysfunction. Clomipramine. Bethanecol chloride. Panic disorder. Pharmacological treatment.

In panic disorder patients, effective pharmacological treatment with antidepressants has been shown to greatly improve the quality of life, but it is often associated with the emergence of sexual dysfunctions. ${ }^{1}$

Sexual dysfunctions are common ${ }^{2-}$ ${ }^{4}$ but systematically underreported side effects. ${ }^{5,6}$ They are, nonetheless, associated with noncompliance, leading to early treatment dropout, treatment nonresponse, and relapse of symptoms. ${ }^{4,7}$

Among the antidepressants, serotonin selective reuptake inhibitors (SSRIs) and clomipramine, may cause more sexual side effects than other antidepressants. ${ }^{6,8,9,10}$ Biochemical mechanisms suggested as causative in- clude the following: 1) increased brain serotonin, particularly affecting 5 $\mathrm{TH} 2$ and 5HT3 receptors; 2) decreased dopamine; 3) central blockade of cholinergic and alpha-1 adrenergic receptors; 4) inhibition of nitric oxide synthetase; 5) elevation of prolactin levels; and 6) peripheral muscarinic blockade. ${ }^{11}$

Clomipramine is considered the gold standard for treatment of panic disorder. ${ }^{12}$ On the other hand, its use is commonly associated with sexual

From the Anxiety Clinic, Department of Psychiatry, Hospital das Clínicas, Faculty of Medicine, University of São Paulo - São Paulo/SP, Brazil. E-mail: amban@amban.org.br

Received for publication on April 19, 2004.

Accepted for publication on July 07, 2004. side effects such as orgasmic dysfunction in up to $20 \%$ to $96 \%$ of patients. ${ }^{5,6,13}$

Clomipramine is the imipramine analogue of chlorpromazine. Compared to other tricyclic antidepressants (TCA), it has a greater effect upon dopamine blockade and serotonin uptake inhibition. ${ }^{14}$ This has implications for prolactin release ${ }^{15}$ and orgasmic dysfunction mediated through 5HT2 receptors. ${ }^{16}$ Moreover, peripheral antimuscarinic ${ }^{17}$ and alpha-adrenergic blockade ${ }^{7,18,19}$ effects have also been implicated in the mechanism of clomipramine-induced orgasmic dysfunctions.

There are few studies of the clinical management of antidepressant-in- 
duced sexual dysfunctions. Case reposts and open trials suggested that yohimbine, ${ }^{20}$ buproprion, ${ }^{21}$ cyproheptadine, ${ }^{22}$ sildenafil citrate, ${ }^{10,23}$ buspirone, ${ }^{6}$ and bethanecol chloride ${ }^{24-26}$ may be effective in antidepressant-induced sexual dysfunctions.

Bethanecol chloride has mixed central and peripheral cholinergic and adrenergic effects. When used in doses of 10 to $100 \mathrm{mg}$ given 30 to $60 \mathrm{~min}$ utes before intercourse, it has been suggested in case reports to be effective in reversing antidepressant-induced anorgasmia. ${ }^{24-26}$ The supposed mechanism of action is the muscarinic agonist-induced potentiation of adrenergic function. ${ }^{17}$

In this study, we further investigated the efficacy of bethanecol for the treatment of clomipramine-induced orgasmic dysfunction in male patients using clomipramine as maintenance treatment for panic disorder in a randomized, double-blind, placebocontrolled, crossover trial.

\section{METHODS}

Twelve panic disorder patients (all male) aged 18 to 65 years gave informed consent to take part in this study. The duration of the orgasmic dysfunction (ejaculatory delay or anorgasmia) was $5.8 \pm 5.8$ (mean \pm standard deviation) months. No patient complained of erectile dysfunction.

All patients were fully remitted and were receiving clomipramine as maintenance treatment. The mean daily dose of clomipramine was $106 \pm$ $64 \mathrm{mg}$ (range: $30-200 \mathrm{mg}$ ), and the duration of treatment was $6.9 \pm 5.4$ months (range: 1 - 18 months). Subjects using other medications were excluded.

Inclusion criteria were absence of sexual dysfunction prior to clomipramine use, presence of normal sexual desire; absence of medical ill- ness or use of other drugs known to interfere with sexual functioning; and no personal history of asthma, coronary insufficiency, or duodenum ulcer.

Subjects were assigned to receive either bethanecol chloride tablets (20 $\mathrm{mg}$, as needed) or placebo in a randomized, double-blind, placebocontrolled, two-period crossover study (Group A = bethanecol 2 weeks/ placebo 2 weeks; Group B = placebo 2 weeks / bethanecol 2 weeks). Patients were given either 2 capsules of $20 \mathrm{mg}$ bethanecol or 2 of placebo in each period and were instructed to take the medication 45 minutes before sexual intercourse on up to 2 occasions in each 2 -week period. Additional tablets were not provided. In order to avoid absorption delays, subjects were instructed to wait 2 hours after full meals.

Patients were evaluated at baseline and at week 2 and 4.

Baseline measures included the Hamilton Depression Rating Scale $\left(\mathrm{HDRS}^{27}\right.$ ), Hamilton Anxiety Scale $\left(\mathrm{HAS}^{28}\right)$, and a visual analog sexual function scale constructed with 6 anchor points (Table 1). Even though this scale measures both erectile and ejaculatory (orgasmic) function, only the orgasmic function measures were analyzed as there were no predicted effects of both clomipramine and bethanecol on erectile functioning.

Table 1 - Visual analog sexual function scale, anchor points.

SEXUAL FUNCTION SCALE

I) Which of the statements below best describes your erection during intercourse. 1-I had no erection.

2-I had some erection, but not enough to penetrate.

3-Loss of erection during or at the beginning of sexual intercourse.

4-Loss of the erection at the end of intercourse due to tiredness.

5-Difficulties in keeping the erection during intercourse but could finish it.

6-Normal erection, as used to be.

II) Which of the statements bellow best describes your effort to reach orgasm (ejaculation): 1-No orgasm.

2-Had an orgasm with extreme effort and tiredness.

3-Clearly needed more effort and concentration.

4-Moderate effort and more time needed to reach orgasm than normally need.

5 -Noted some delay or difficulty, almost normal.

6-Usual time and effort needed to reach an orgasm. 
Table 2 - Individual data on the orgasmic functioning scale, score at baseline and best score at each treatment period.

\begin{tabular}{llcccc}
\hline Patient & age & Clomipramine dose & Baseline & Placebo & Bethanechol \\
\hline 1 & 44 & $30 \mathrm{mg}$ & 0 & 0 & 4 \\
2 & 48 & $175 \mathrm{mg}$ & 2 & 2 & 8 \\
3 & 40 & $75 \mathrm{mg}$ & 2 & 2 & 8 \\
4 & 40 & $40 \mathrm{mg}$ & 2 & 8 & 8 \\
5 & 43 & $50 \mathrm{mg}$ & 4 & 6 & 8 \\
6 & 48 & $75 \mathrm{mg}$ & 2 & 4 & 6 \\
7 & 31 & $200 \mathrm{mg}$ & 0 & 0 & 4 \\
8 & 49 & $75 \mathrm{mg}$ & 2 & 0 & 4 \\
9 & 65 & $50 \mathrm{mg}$ & 0 & 0 & 0 \\
10 & 53 & $150 \mathrm{mg}$ & 2 & 2 & 8 \\
\hline
\end{tabular}

\section{DISCUSSION}

The small sample size imposes limits on the generalization of the present results. Nevertheless, we found an improvement in the patients sexual functioning after bethanecol. This effect was not related to psychopathological changes or clomipramine dosing changes during the study. In fact, all patients were in remission and on maintenance doses during this trial.

The mechanism of action of bethanecol is still not fully understood. It has been proposed that an imbalance between cholinergic and adrenergic function is responsible for tricyclic antidepressant-induced orgasmic dysfunction. ${ }^{17}$ These authors hypothesized a muscarinic agonist-induced potentiation of adrenergic function as an explanation for the effects of bethanecol. In fact yohimbine, an alfa- 2 adrenergic antagonist, was also shown to reverse clomipramineinduced anorgasmia. ${ }^{20}$ More recently, buproprion, which also promotes central adrenergic potentiation, has also been shown to be useful in SSRI-induced sexual dysfunction. ${ }^{30}$ On the other hand, mazindol, an anorectic drug that increases sympathetic tonus, provokes anorgasmia that was reversed by bethanecol. ${ }^{25}$

We conclude that bethanecol chloride may be a valid option in the treatment of clomipramine-induced orgasmic dysfunction.

\section{ACKNOWLEDGMENTS}

The authors thank Cristiane Pinheiro Lima, for editorial assistance and Marcus Estanislau, for statistical analysis.

\section{RESUMO}

BERNIK M e col. O uso do cloridrato de betanecol no tratamento da disfunção orgásmica induzida pela clomipramina em pacientes do sexo masculino. Rev. Hosp. Clín. Fac. Méd. S. Paulo 59(6):357-360, 2004.

OBJETIVO: Investigar se o uso do cloridato de betanecol é uma alternativa útil no manejo clínco da disfunção orgásmica induzida pela clomipramina, relatada por até $96 \%$ dos usuários do sexo masculino.

MÉTODOS: Foram estudados 12 pacientes do sexo masculino em remissão completa de transtorno de pânico porém com queixas de disfunção orgásmica grave secundária ao uso da clomipramina. Os pacientes foram aleatoriamente distribuídos ao tratamento com cloridrato de betanecol $(20 \mathrm{mg}$ quando necessário) ou placebo em um estudo duplo cego "crossover" de dois períodos.

RESULTADOS: Foi observado um benefício claro no período de uso da droga ativa. Não foram observados efeito placebo ou "carry-over" nos pacientes inicialmete alocados ao medi- camento ativo.

CONCLUSÕES: Os resultados deste estudo sugerem que o cloridato de betanecol, usado em doses únicas, 45 minutos antes da relação sexual, pode ser útil em pacientes do sexo masculino apresentado disfunção orgásmica secundária ao uso da clomipramina.

UNITERMOS: Disfunção orgásmica. Clomipramina. Cloridrato de betanecol. Transtorno de pânico. Tratamento farmacológico.

\section{REFERENCES}

1. Mendlowicz MV, Stein MB. Quality of life in individuals with anxiety disorders. Am J Psychiatry 2000;157:669-82.
2. Ferguson JM. The effects of antidepressants on sexual functioning in depressed patients: a review. J Clin Psychiatry 2001; 62:22-34. 
3. Montgomery SA, Baldwin DS, Riley A. Antidepressant medications: a review of the evidence for drug-induced sexual dysfunction. J Affect Disorders 2002;69:119-140.

4. Zajecka J. Strategies for the treatment of antidepressant-related sexual dysfunction. J Clin Psychiatry 2001;62:35-43.

5. Monteiro WO, Noshirvani HF, Marks IM. Anorgasmia from clomipramine in obsessive-compulsive disorder: a controlled trial. Br J Psychiatry 1987;151:107-12.

6. Rothschild AJ. New directions in the treatment of antidepressantinduced sexual dysfunction. Clin Ther 2000;22:42-61.

7. Balon R, Yeragani VK, Polil R. Sexual dysfunction during antidepressant treatment. J Clin Psychiatry 1993;54:209-12.

8. Baldwin DS. Psychotropic drugs and sexual dysfunction. Int Rev Psychiatry 1995;7:261-73.

9. Lane RM. A critical review of selective serotonin reuptake inhibitor-related sexual dysfunction; incidence, possible aetiology and implications for management. J Psychopharmacology 1997;11:72-82.

10. Fava M, Rankin M. Sexual functioning and SSRIs. J Clin Psychiatry 2002;63:13-6.

11. Keltner NL, McAfee KM, Taylor CL Mechanisms and treatments of SSRI-induced sexual dysfunction. Perspect Psychiatr Care 2002;38(3):111-6.

12. Gentil V, Lotufo-Neto F, Andrade L. Clomipramine, a better reference drug for panic/agoraphobia. I. Effectiveness comparison with imipramine. J Psychopharmacology 1993; $7: 316-24$.

13. Beaumont G, Mayes A. Do task and sex differences influence the visual evoked potential? Psychophysiology 1977;14:545-50.

14. Blackwell B Antidepressant Drugs. In: DUKES MN. Meyler's Side Effects of Drugs. Elsevier, Amsterdam. 1984. p. 24-61.

15. Jones RD, Luscombe DK, Groom GV. Plasma prolactin concentration in normal subjects and depressive patients following oral clomipramine. Post Grad Med Journal 1977; $53: 166$.

16. Pomerantz SM, Hepner BC, Wertz JM. Serotonergic influences on male sexual behavior of rhesus monkeys: effects of serotonin agonists. Psychopharmacology (Berl). 1993;111:4754.

17. Sorscher SM, Dilsaver SC. Antidepressant-induced sexual dysfunction in men: due to cholinergic blockade? J Clin Psychopharmacology 1986;6:53-5.
18. Beaumont G. Sexual side-effects of clomipramine (Anafranil). J Int Med Research 1977;5(1 Suppl):469.

19. Aizenberg D, Zemishlany Z, Hermesh H. Painful ejaculation associated with antidepressants in four patients. J Clin Psychistry $1991 ; 52: 11$

20. Price J, Grunhaus LJ. Treatment of clomipramine-induced anorgasmia with yohimbine: a case report. J Clin Psychiatry $1990 ; 51: 32-3$

21. Walker PW, Cole JO, Gardner EA. Improvement in fluoxetineassociated sexual dysfunction in patients switched to bupropion. J Clin Psychiatry 1993;54:459-65.

22. Aizenberg D, Zemishlany Z, Weizman A. Cyproheptadine treatment of sexual dysfunction induced by serotonin reuptake inhibitors. Clin Neuropharmacol 1995;18:320-4.

23. Nurnberg HG, Seidman SN, Gelenberg AJ, Fava M, Rosen R, Shabsigh R, et al. Depression, antidepressant therapies, and erectile dysfunction: clinical trials of sildenafil citrate in treated and untreated patients with depression. Urology 2002;60:58 66.

24. Segraves RT. Reversal by bethanecol of imipramine-induced ejaculatory dysfunction. Am J Psychiatry 1987;144:1243-4.

25. Yager J. Bethanecol chloride can reverse erectile and ejaculatory dysfunction induced by tricyclic antidepressants and mazindol: case report. J Clin Psychiatry 1986;47:210-1.

26. Gross MD. Reversal by bethanecol of sexual dysfunction caused by anticholinergic antidepressants. Am J Psychiatry 1982 139:1193-4.

27. Hamilton M. A rating scale for depression. J Neurol Neurosurg Psychiatry 1960;23:56-62.

28. Hamilton $\mathrm{M}$. The assessment anxiety states by rating. Br $\mathrm{J}$ med Psychol 1959;32:50-5.

29. Krauth J - Distribution - free statistics. An application-oriented approach. In: HUSTON JP. Techniques in the Behavioral and Neural Sciences, vol. 2. Elsevier, Amsterdan. 1988. p. 99 107.

30. Kennedy SH, McCann SM, Masellis M, Mclntyre RS, Raskin J, Mckay G, Baker GB et al. Combining bupropion SR with venlafaxine, paroxetine, or fluoxetine: a preliminary report on pharmacokinetic, therapeutic, and sexual dysfunction effects. J Clin Psychiatry 2002;63:181-6. 